\title{
Small Intestinal Squamous Cell Carcinoma
}

National Cancer Institute

\section{Source}

National Cancer Institute. Small Intestinal Squamous Cell Carcinoma. NCI Thesaurus.

Code C43534.

A carcinoma that arises from the small intestine. It is composed of malignant squamous cells. 